\title{
Reliability of commercially available immunocytochemical markers for identification of neuroendocrine differentiation in bronchoscopic biopsies of bronchial carcinoma
}

\author{
JR Gosney, MA Gosney, Michael Lye, SA Butt
}

\begin{abstract}
Background - Although neuroendocrine differentiation occurs quite commonly in non-small cell bronchial malignancies, its biological significance and implications for management remain uncertain. Determining these facts requires its recognition early, ideally at diagnosis, which is usually made on tissue from bronchoscopy, but the best means of its detection in such material is unclear. A prospective comparative study was performed of 10 commercially available antisera to a series of markers of neuroendocrine differentiation, to test their efficacy when applied to fibreoptic bronchoscopy biopsy specimens.
\end{abstract}

Methods - Expression of chromogranin A, synaptophysin, neurone-specific enolase, protein gene product $9 \cdot 5$, the $\mathrm{BB}$ isoenzyme of creatine kinase, gastrin releasing peptide, adrenocorticotrophic hormone, calcitonin, calcitonin gene related peptide, and leucine enkephalin was sought by immunolabelling of bronchoscopic biopsy tissue from 83 primary bronchial carcinomas, 22 of them of small cell type.

Results - Only synaptophysin and chromogranin were sensitive and specific enough for neuroendocrine differentiation to discriminate between small cell and non-small cell lesions, whereas protein gene product 9.5 and creatine kinase were neither particularly sensitive nor specific and neurone-specific enolase actually labelled more non-small cell tumours than small cell lesions. Of the five secretory products sought, only gastrin releasing peptide was detectable in just one tumour. Three squamous and two morphologically undifferentiated tumours immunolabelled for synaptophysin and chromogranin, almost certainly indicating neuroendocrine differentiation in the absence of small cell morphology.

Conclusions - Of the markers studied, only synaptophysin and chromogranin were sufficiently specific and sensitive for neuroendocrine differentiation to justify their inclusion in any panel of antibodies used in its detection in tissue obtained at fibreoptic brochoscopy.

(Thorax 1995;50:116-120)

Keywords: immunocytochemical markers, neuroendocrine differentiation, bronchial carcinoma.

Malignant bronchial tumours are classified according to their microscopical appearance into two major categories - small cell and nonsmall cell ${ }^{1}$ - the former being characterised by neuroendocrine differentiation. ${ }^{2}$ The importance of this basic division, the mainstay of the classification of the disease for more than a quarter of a century, arises mainly from the fact that it is a crucial factor in determining treatment.

Doubt has been cast on this neat distinction, however, by studies revealing that neuroendocrine differentiation is not confined to bronchial malignancies of small cell type, but is also consistently demonstrable in a proportion of morphologically non-small cell tumours. ${ }^{3-8}$ Although there are various ways in which neuroendocrine differentiation can be detected, ${ }^{2}$ the most ready means for the histopathologist is by seeking the presence of one or more substances reflecting this line of differentiation which can be detected by immunochemistry. These substances fall into two groups. The first comprises cytoplasmic enzymes and components of intracellular secretory systems such as neurone-specific enolase (NSE), ${ }^{9}$ protein gene product (PGP) $9 \cdot 5,{ }^{10}$ synaptophysin, ${ }^{11}$ the $\mathrm{BB}$ isoenzyme of creatine kinase (CK-BB), ${ }^{12}$ and chromogranin A. ${ }^{13}$ The second comprises hormonal secretory products such as gastrin releasing peptide (GRP), adrenocorticotrophic hormone (ACTH), calcitonin, calcitonin gene related peptide, and leucine (Leu-) enkephalin. ${ }^{14-16}$ Antibodies to these and similar substances have been used in many studies of neuroendocrine differentiation in pulmonary tumours ${ }^{3-8} 17-24$ and their efficacy as markers of it has long been debated. In this study, however, we wished to Revised version received 10 August 1994 
Table 1 Details of antisera to neurendocrine markers

\begin{tabular}{|c|c|c|c|}
\hline Marker & Source & Dilution & Control tissue \\
\hline Neurone specific enolase & $\begin{array}{l}\text { Dako Ltd, High Wycombe, } \\
\text { Bucks, UK }\end{array}$ & $1: 400$ & Human pancreatic islets \\
\hline Protein gene product 9.5 & $\begin{array}{l}\text { Biogenesis, Bournemouth, } \\
\text { UK }\end{array}$ & $1: 800$ & Human pancreatic islets \\
\hline Synaptophysin & ICN Biomedicals, Bucks, UK & $1: 50$ & Human pancreatic islets \\
\hline $\begin{array}{l}\text { Brain isoenzyme of } \\
\text { creatine kinase }\end{array}$ & $\begin{array}{l}\text { Biogenesis, Bournemouth, } \\
\text { UK }\end{array}$ & $1: 500$ & Rat cerebral cortex \\
\hline Chromogranin A & $\begin{array}{l}\text { Dako Ltd, High Wycombe, } \\
\text { Bucks, UK }\end{array}$ & $1: 500$ & Human pancreatic islets \\
\hline Gastrin releasing peptide & $\begin{array}{l}\text { Peninsula, St Helens, } \\
\text { Merseyside, UK }\end{array}$ & $1: 4000$ & $\begin{array}{l}\text { Human fetal pulmonary } \\
\text { endocrine cells }\end{array}$ \\
\hline Adrenocorticotrophin & $\begin{array}{l}\text { Dako Ltd, High Wycombe, } \\
\text { Bucks, UK }\end{array}$ & $1: 1000$ & $\begin{array}{l}\text { Human pituitary } \\
\text { corticotrophs }\end{array}$ \\
\hline Calcitonin & $\begin{array}{l}\text { Dako Ltd, High Wycombe, } \\
\text { Bucks, UK }\end{array}$ & $1: 2000$ & $\begin{array}{l}\text { Human medullary thyroid } \\
\text { carcinoma }\end{array}$ \\
\hline $\begin{array}{l}\text { Calcitonin gene related } \\
\text { peptide }\end{array}$ & $\begin{array}{l}\text { Peninsula, St Helens, } \\
\text { Merseyside, UK }\end{array}$ & $1: 4800$ & $\begin{array}{l}\text { Human medullary thyroid } \\
\text { carcinoma }\end{array}$ \\
\hline Leu-enkephalin & $\begin{array}{l}\text { CRB, Northwich, Cheshire, } \\
\text { UK }\end{array}$ & $1: 800$ & Human adrenal medulla \\
\hline
\end{tabular}

concentrate specifically on their application to the small tissue biopsy samples obtained at fibreoptic bronchoscopy. Our aims were (1) to see how prevalent positivity for these substances was in small cell carcinoma and thus how sensitive and specific they were as markers of neuroendocrine differentiation as it is manifested in these tumours, and (2) to assess the frequency of neuroendocrine differentiation in squamous and adenocarcinomas and in tumours considered morphologically unclassifiable.

\section{Methods}

A series of formalin fixed paraffin wax embedded tissue biopsy specimens from 83 consecutive newly diagnosed primary bronchial carcinomas was studied. Serial sections were stained with haematoxylin and eosin to show basic morphology and by the periodic acid Schiff and alcian blue methods for demonstration of mucins. They were then immunolabelled by the avidin-biotin complex (ABC) method $^{25}$ for 10 markers of neuroendocrine differentiation (table 1). In each case the primary antiserum was incubated with tissue sections for one hour. This was then linked to avidin-biotin horseradish peroxidase complex via biotinylated donkey anti-rabbit serum at a dilution of 1:200 applied for 30 minutes. Diaminobenzidine was the chromogen. Control tissues are shown in table 1. All antisera were well characterised by the manufacturers so that absorption studies were not considered necessary.

Tumours were classified as either small cell or non-small cell on the basis of their morphology, ${ }^{1}$ the latter being either squamous (epidermoid) or adenocarcinomas. Any tumour considered not to be of small cell type, but which showed no features of squamous or glandular differentiation either, was considered morphologically undifferentiated and, therefore, unclassifiable.

Immunolabelled sections were assessed according to whether they were positive or negative for the marker in question. Only those in which there was distinct cytoplasmic labelling of confluent sheets of cells amounting to more than $10 \%$ of the population (figs 1 and 2) were deemed positive. Tumours in which only occasional isolated cells were labelled, or in which labelling was weak and indistinct even after repeated labelling, were considered to be negative. The specificity and sensitivity of the various markers for small cell morphology were noted. Specificity was a measure of the number of negative tumours actually observed in relation to the number expected to be negative - that is, none. Sensitivity was a measure of the number of positive tumours actually observed in relation to the number expected to be positive - that is, all. The relation between expression of markers and histological tumour type was recorded and assessed statistically using Fisher's exact test (two-tailed).

\section{Results}

Of 83 biopsy specimens 37 were from squamous tumours, 15 from adenocarcinomas, and 22 from tumours of small cell type. Nine had no specific features and were considered morphologically unclassifiable.

Not all tissue biopsy specimens were analysed for all 10 markers because, in some cases, the tumour tissue was insufficient. All, however, were immunolabelled for at least eight markers.

The relation between morphology and expression of neuroendocrine markers for those tumours which could be specifically categorised morphologically as either squamous, adenocarcinoma, or small cell carcinoma is shown in table 2 where squamous and adenocarcinomas are considered together as a single group of non-small cell lesions. Synaptophysin was the most closely related to a small cell morphology, being positive in 16 of 19 tumours of this type (fig 1A), but in only three of 49 with a non-small cell morphology. The difference was highly significant $(p<0.00001)$. A less marked but significant relation with small cell morphology was found for chromogranin A $(p<0.0001)$. This marker, like synaptophysin, was expressed more commonly by small cell tumours (eight out of 21 ;

Table 2 Relation of neuroendocrine markers to morphological types of bronchial carcinoma*

\begin{tabular}{|c|c|c|c|c|c|c|c|c|c|c|c|c|}
\hline & \multicolumn{2}{|c|}{$S Y N$} & \multicolumn{2}{|c|}{ CHR } & \multicolumn{2}{|c|}{$P G P$} & \multicolumn{2}{|c|}{$N S E$} & \multicolumn{2}{|c|}{$C K-B B$} & \multicolumn{2}{|l|}{$G R P$} \\
\hline & + & - & + & - & + & - & + & - & + & - & + & - \\
\hline $\begin{array}{l}\text { Squamous and adenocarcinoma } \\
\text { (non-small cell) }\end{array}$ & 3 & 46 & 3 & 48 & 8 & 42 & 24 & 26 & 18 & 33 & 0 & 50 \\
\hline $\begin{array}{l}\text { Small cell carcinoma } \\
\text { p value (two-tailed Fisher's exact) }\end{array}$ & \multicolumn{2}{|c|}{$\begin{array}{ll}16 & 3 \\
0.00001\end{array}$} & \multicolumn{2}{|c|}{$\begin{array}{ll}8 & 13 \\
0 \cdot 0001\end{array}$} & \multicolumn{2}{|c|}{${ }_{>0}^{6} \cdot 1$} & \multicolumn{2}{|c|}{$\begin{array}{l}3 \\
<0.005\end{array}$} & $\begin{array}{l}6 \\
>0 \cdot 1\end{array}$ & 16 & $\begin{array}{l}1 \\
<0 \cdot 5\end{array}$ & 21 \\
\hline Morphologically unclassified carcinoma & 3 & 6 & 2 & 7 & 3 & 5 & 2 & 7 & 2 & 7 & 0 & 9 \\
\hline
\end{tabular}

$\mathrm{SYN}=$ synaptophysin; $\mathrm{CHR}=$ chromogranin; $\mathrm{PGP}=$ protein gene product $9 \cdot 5 ; \mathrm{NSE}=$ neurone-specific enolase; $\mathrm{CK}-\mathrm{BB}=$ brain isoenzyme of creatine kinase; GRP = gastrin releasing peptide; $+=$ positive labelling; $-=$ negative labelling (see text for criteria for positivity).

*No tumour labelled for adrenocorticotrophin, calcitonin, calcitonin gene related peptide or Leu-enkephalin. 

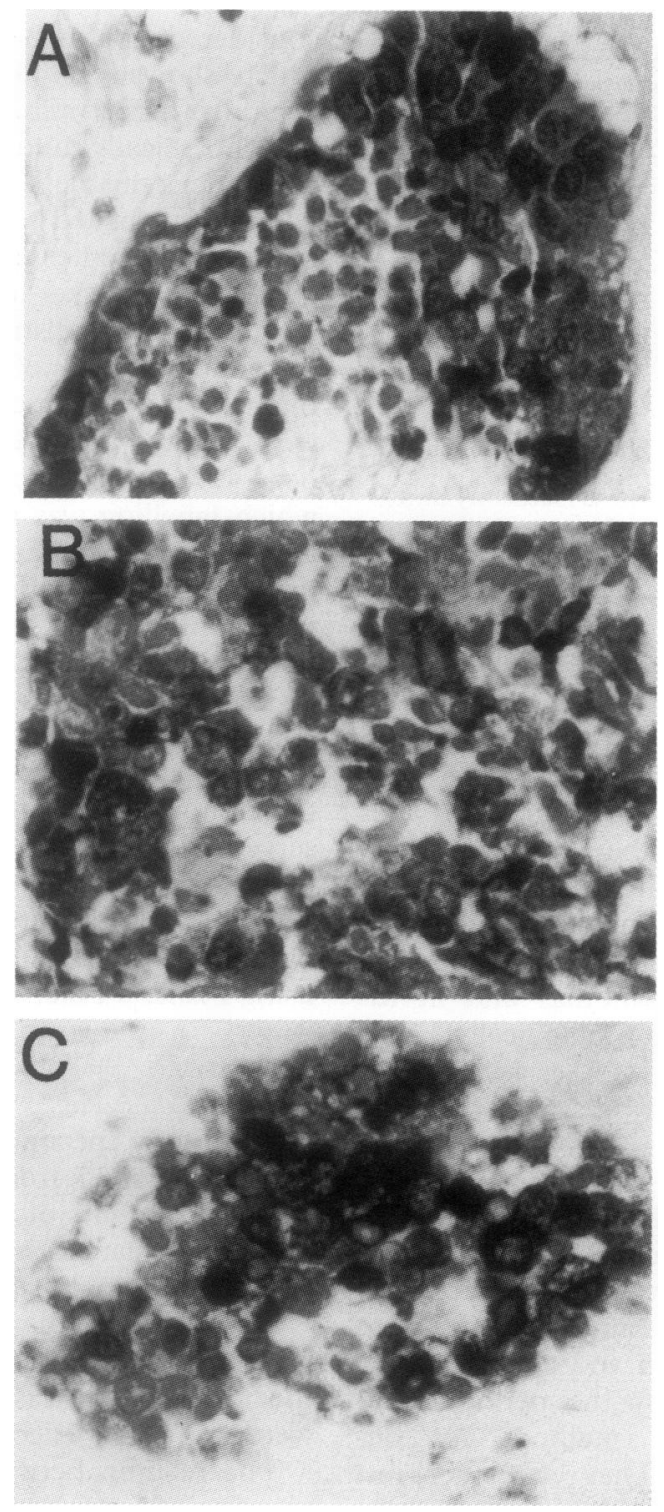

Figure 1 Three small cell carcinomas showing strong confluent immunoreactivity for synaptophysin $(A)$, chromogranin (B), and gastrin releasing peptide (C). $A B C$ technique; magnifications $\times 600$.

fig lB) than by squamous or adenocarcinomas (three out of 51), but was less sensitive for small cell carcinoma, 13 of them failing to express it. The three non-small cell tumours labelling for both synaptophysin and chromogranin A were the same; all three had been typed morphologically as poorly differentiated squamous carcinomas.

In contrast, NSE was expressed more often by the non-small cell ( 24 out of 50; fig $2 \mathrm{~A}$ ) than the small cell (three out of 22) tumours and the difference was statistically significant $(\mathrm{p}<0.005)$. Both PGP 9.5 (fig 2B) and CK-BB (fig 2C) labelled a number of morphologically non-small cell as well as small cell lesions including, in the case of PGP 9.5, the three poorly differentiated squamous carcinomas which were positive for synaptophysin and chromogranin A. Just one small cell carcinoma showed positive immunoreactivity for GRP (fig lC). No tumour immunolabelled for any of the remaining four hormonal products sought.

Of the nine tumours which could not be classified on morphological grounds, one was positive for five markers (synaptophysin, chromogranin A, PGP 9.5, NSE, and CK-BB), one for four (synaptophysin, chromogranin A, NSE, and CK-BB) and one for three (synaptophysin, chromogranin A, and PGP 9.5). The remaining six tumours were negative for all markers.

\section{Discussion}

In this study expression of only synaptophysin and chromogranin A could be used to discriminate with any degree of consistency between small cell and non-small cell tumours, a finding in keeping with other studies of neuroendocrine differentiation in pulmonary neoplasms. ${ }^{6}$ Both of these substances are components of the secretory apparatus which characterises neuroendocrine cells and the chromogranins are the major component of the matrix of the dense core vesicles which are the hallmark of this line of differentiation. They are, therefore, undoubted markers of the neuroendocrine phenotype, and are reliable markers of neuroendocrine differentiation as it is manifest in small cell carcinoma of the bronchus using the methods we have employed.

In contrast to synaptophysin and chromogranin A, PGP 9.5 and CK-BB labelled fewer of the small cell and more of the non-small tumours, and did not discriminate between them. NSE was particularly prevalent amongst the latter. We interpret this as indicating a lack of specificity of these substances for the neuroendocrine phenotype in pulmonary tumours, as observed in previous studies of resected specimens. ${ }^{31819212426}$ The use of CK-BB as a marker of neuroendocrine differentiation in pulmonary neoplasms has been less well investigated. Although some have found its immunochemical detection to be a useful marker of neuroendocrine differentiation, ${ }^{20} 27$ this was not the case in our study.

Apart from GRP, ${ }^{19} 21242628-30$ hormonal products have been little studied as markers of neuroendocrine differentiation in pulmonary neoplasms, despite the fact that their synthesis and secretion by those showing neuroendocrine differentiation is well known. ${ }^{2}$ None of the five we sought served as an indicator of neuroendocrine differentiation, all but GRP being undetectable in the biopsy specimens examined. The expression of these secretory products is particularly heterogeneous within pulmonary tumours, ${ }^{2}$ however, and they might be of more value in detecting neuroendocrine differentiation in resected lesions.

There are many reasons why, despite their undoubted neuroendocrine phenotype, many of our small cell tumours did not express the substances sought. Inadequate sampling might have been responsible, as expression varies within neoplastic cell populations and the tissue obtained at fibreoptic bronchoscopy is a tiny fraction of the whole tumour. Use of inappropriate antisera might have been responsible, especially when seeking secretory products which, in tumours, are often synthesised in precursor or variant forms and undergo numerous changes during packaging and 

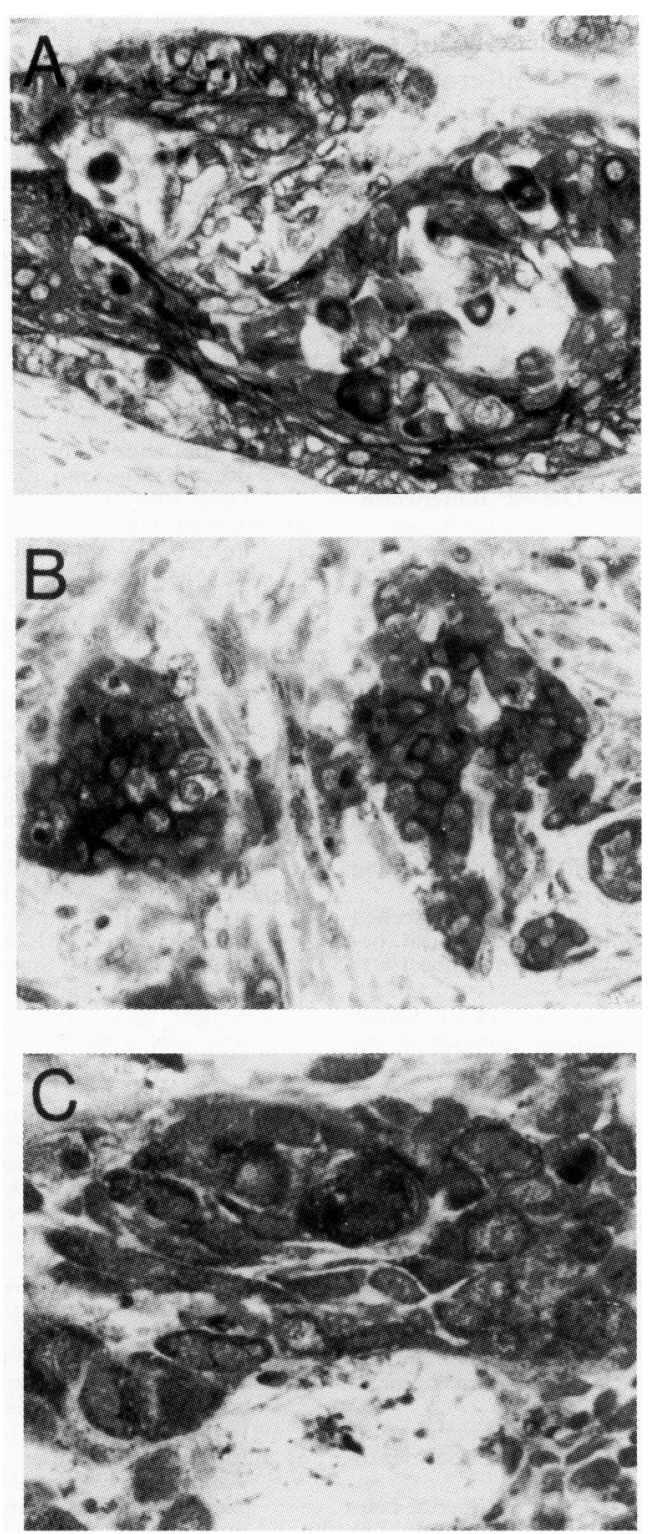

Figure 2 Three morphologically squamous differentiated (non-small cell) carcinomas showing strong confluent immunoreactivity for neurone-specific enolase $(A)$, protein gene product $9 \cdot 5(B)$, and the brain isoenzyme of creatine kinase (C). ABC technique; magnifications $\times 600$.

transport in the secretory apparatus. Although they were well characterised, only one antibody was used for each antigen studied and detection might have been improved by the use of groups recognising different epitopes, but this was outside the scope of the study. Detection might also have been improved by increasing the concentration of antisera, but the dilutions we used were those providing an optimal signal to background ratio and we did not feel that this was justified.

It is more probable that our negative results reflect the true situation. Although small cell tumours are characterised by neuroendocrine differentiation, they are poorly differentiated neoplasms and its expression is subtle; ${ }^{2}$ dense core vesicles may be few or even absent, cytoplasmic enzymes characteristic of neuroendocrine differentiation are often lost, and secretory products may be synthesised in abnormal forms or in such small amounts as to be undetectable with many antisera. It may well be that substances such as the chromogranins and, in particular, synapto- physin, persist in sufficient concentration in these tumours even when other indicators of their neuroendocrine differentiation are absent or undetectable.

There are two possible explanations as to why so many morphologically non-small cell tumours should display an apparent neuroendocrine phenotype. It might be artefactual; antisera recognising neuroendocrine differentiation might cross react with nonspecific antigens borne by non-small cell tumours or might label antigens other than those they were developed to detect. There is, however, a large body of evidence ${ }^{2}{ }^{6}$ which suggests that morphologically non-small cell tumours often contain elements of neuroendocrine differentiation and that it might influence the way such tumours behave and respond to management. ${ }^{4-726}$

If synaptophysin and chromogranin $\mathrm{A}$ are accepted as accurate markers of neuroendocrine differentiation in pulmonary tumours it was, by these criteria, present in three of the non-small cell tumours studied (all poorly differentiated squamous lesions) and two of the morphologically undifferentiated tumours. In the absence of any agreed criteria for its detection, estimates of its prevalence have varied widely. ${ }^{3-7}$ Varying the dilutions of antibodies and the criteria for the detection of positivity when immunolabelling non-small cell bronchial carcinomas for neuroendocrine markers results in positivity rates between $<10 \%$ and $>90 \%,{ }^{31}$ and a consensus on criteria for the recognition of neuroendocrine differentiation in such tumours is essential. The present study highlights that the choice of neuroendocrine markers is crucial since some, such as PGP 9.5, CK-BB and NSE, appear to detect substances which are not specific for such differentiation and others, such as hormonal products, detect substances which may be specific for the neuroendocrine phenotype but are often absent from the neoplastic population under study.

Perhaps the use of complementary nonimmunohistochemical methods for detection of neuroendocrine differentiation might be of value. Electron optical detection of dense core vesicles is difficult because of sampling problems, the precise identification of these organelles, and the practical difficulties of obtaining optimum fixation particularly with small biopsy samples. In an alternative approach Brambilla et $a l^{32}$ compared the use of biochemical determination of enolase activity and isoenzyme distribution with immunolabelling for various markers including gamma enolase and chromogranin. Whereas the latter were of low specificity and sensitivity respectively, biochemical determination of enolase activity and isoenzymes were highly sensitive and specific for the neuroendocrine phenotype, especially when combined with immunochemical detection of neural cell adhesion molecules.

The importance of the detection of neuroendocrine differentiation lies not so much in distinguishing small cell from non-small cell carcinoma when morphology is equivocal, but 
in identifying a subset of non-small cell tumours which might behave and respond differently to treatment. It is suggested that antibodies to synaptophysin and chromogranin A are useful members of any panel designed for routine recognition of this subset in specimens taken at diagnostic bronchoscopy.

The authors would like to thank the pathologists at Glan Clwyd Hospital, Clwyd and Fazakerley District General Hospita Liverpool, for their cooperation. The work was part of a study supported by the North West Cancer Research Fund.

1 World Health Organisation. Histological typing of lung tumours. Am 7 Clin Pathol 1982;77:123-36.

2 Gosney JR. Pulmonary endocrine pathology: endocrine cells and endocrine tumours of the lung. Oxford: ButterworthHeinemann, 1992.

3 Linnoila RI, Mulshine JL, Steinberg SM, Funa K, Matthews MJ, Cotelingam JD, et al. Neuroendocrin differentiation in endocrine and non-endocrine lung carcinomas. Am f Clin Pathol 1988;90:641-52.

4 Berendsen HH, de Leij L, Poppema S, Postmus PE, Sluiter $\mathrm{HJ}$, The $\mathrm{H}$. Clinical characterisation of non-small cell lung cancer tumours showing neuroendocrine differentiation features. F Clin Oncol 1989;7:1614-20.

5 Graziano SL, Mazid R, Newman N, Tatum A, Oler A Mortimer JA, et al. The use of neuroendocrine immunoperoxidase markers to predict chemotherapy response in patients with non-small cell lung cancer. $\mathcal{f}$ Clin sponse in patients with

6 Sheppard MN. Neuroendocrine differentiation in lung tumours. Thorax 1991;46:843-50.

7 Sundaresen V, Reeve JG, Stenning S, Stewart S, Bleehen NM. Neuroendocrine differentiation and clinical behaviour in non-small cell lung tumours. Br f Cancer 1991 64:333-8.

8 Travis WD, Linnoila RI, Tsokos MG, Hitchcock CL, Cutler GB, Nieman L, et al. Neuroendocrine tumours of the lung with proposed criteria for large-cell neuroendocrine carcinoma. Am ₹ Surg Pathol 1991;15:529-53.

9 Schmechel DE, Marangos PJ, Brightman MW. Neuron specific enolase is a marker for peripheral and central specific enolase is a marker for peripheral
neuroendocrine cells. Nature 1978;276:834-6.

10 Thempson RJ, Doran JF, Jackson P, Dhillon AP, Rode J. PGP 9.5 - a new marker for vertebrate neurones and PGP 9.5 - a new marker for vertebrate neuro

11 Wiedenmann B, Franke WW, Kuhn C, Moll R, Gould VE Synaptophysin: a marker protein for neuroendocrine cells and neoplasms. Proc Natl Acad Sci USA 1986;83:3500-4

12 Gazdar AF, Zweig MH, Carney DN, Steirteghen ACW, Baylin SB, Minna JD. Levels of creatine kinase and its $\mathrm{BB}$ isoenzyme in lung cancer specimens and cultures. Cancer Res 1981;41:2773-7.

13 Wilson BS, Lloyd RV. Detection of chromogranin in neuroendocrine cells with a monoclonal antibody. $A m \mathcal{F}$ Pathol 1984:115:458-68.

14 Gould VE, Warren WH, Memoli VA. Neuroendocrine neoplasms of the lung. In: Becker KL, Gazdar AF, eds. The endocrine lung in health and disease. Philadelphia: Saunders, endocrine lung

15 Yamaguchi K, Abe K, Adachi I, Kimura S, Suzuki M, Shimada A, et al. Peptide hormone production in primary lung tumours. Rec Res Cancer Res 1985;99:107-16.
16 Kasurinen J, Syrjanen KJ. Peptide hormone immunoreactivity and prognosis in small-cell carcinoma of the lung. Respiration 1986;49:61-7.

17 Sheppard MN, Corrin B, Bennett MH, Marangos PJ, Bloom SR, Polak JM. Immunocytochemical localization of neuron specific enolase in small cell carcinomas and carneuron specific enolase in small cell carcinomas and car-

cinoid tumours of the lung. Histopathology 1984;8:171-81.
18 Dhillon AP, Rode J, Dhillon DP, Moss E, Thompson RJ, Spiro SG, et al. Neural markers in carcinoma of the lung Br f Cancer 1985;51:645-52.

19 Said JW, Vimadalal S, Nash G, Shintaku IP, Heusser RC, Sassoon AF, et al. Immunoreactive neuron specific enolase, bombesin, and chromogranin as markers for neuroendocrine lung tumours. Hum Pathol 1985;16:236-40.

20 Nakajima T, Shimosato Y, Morinaga S, Teresaki T, Tsumuraya M, Yamaguchi K, et al. Immunohistochemical study of small cell lung carcinoma with special reference to the neuroendocrine markers aromatic L-amino acid decarboxylase and gastrin-releasing peptide. $\mathfrak{f p n}_{\mathrm{p}} \mathcal{f} \mathrm{Clin}$ Oncol 1986;16:223-33.

21 Addis BJ, Hamid Q, Ibrahim NBN, Fahey M, Bloom SR, Polak JM. Immunohistochemical markers of small cel carcinoma and related neuroendocrine tumours of the lung. F. Pathol 1987;153:137-50.

22 Bepler G, Jaques G, Koehler A, Gropp C, Havemann K. Markers and characteristics of human SCLC cell lines. f Cancer Res Clin Oncol 1987;113:253-9.

23 Gould VE, Wiedenmann B, Lee I, Schwechheimer K, Dockhorn-Dworniczak B, Radosevich JA, et al. Synaptophysin expression in neuroendocrine neoplasms as determined by immunocytochemistry. Am ₹ Pathol 1987;126:243-57.

24 Kayser K, Schmid W, Ebert W, Widenmann B. Expression of neuroendocrine markers (neuron specific enolase, synaptophysin and bombesin) in carcinoma of the lung. Pynaptophysin and bombesin)

25 Hsu S. Raine L, Fanger H. Use of avidin-biotin-peroxidase complex (ABC) in immunoperoxidase techniques. $\mathcal{F}$ Histo chem Cytochem 1981;29:577-80.

26 Mooi WJ, Dewar A, Springall D, Polak JM, Addis BJ. Nonsmall cell lung carcinomas with neuroendocrine features. A light microscopic, immunohistochemical and ultrastructural study of 11 cases. Histopathology 1988;13:329 37.

27 Ariyoshi Y, Kato K, Ueda R, Takaheshi T, Sato T, Akatsuka $\mathrm{H}$, et al. Biological and clinical implication of neuron$\mathrm{H}$, et al. Biological and clinical implication of neuronspecific enolase and creatine kinase BB in

28 Hamid. Expression of gastrin-releasing peptide (human bombesin) gene in large cell undifferentiated carcinoma of the lung. Pathol 1990;161:145-51.

29 Bostwick DG, Roth KA, Evans CJ, Barchas JD, Bensch KG. Gastrin-releasing peptide, a mammalian analog of bombesin, is present in human neuroendocrine lung tumours. Am $\mathcal{F}$ Pathol 1984;117:195-200.

30 Chejfech G, Lee I, Warren WH, Gould VE. Bombesin in human neuroendocrine (NE) neoplasms. Peptides 1985;6: 107-12.

31 Burnett HE, Spedding AV, Pendleton N, Kenyon WE Walker C. Criteria for assessing the neuroendocrine Walker C. Criteria for assessing the neuroendocrine phenotype and its incidence in

32 Brambilla E, Veale D, Moro D, Morel F, Dubois F, Brambilla C. Neuroendocrine phenotype in lung cancers. Com parison of immunohistochemistry with biochemical determination of enolase isoenzymes. Am F Clin Pathol 1992 98:88-97. 